\title{
Three New Races of the Spinach Downy Mildew Pathogen Identified by a Modified Set of Spinach Differentials
}

\author{
B. M. Irish, United States Department of Agriculture-Agricultural Research Service, Tropical Agriculture Research \\ Station, Mayaguez, PR 00680; J. C. Correll, Department of Plant Pathology, University of Arkansas, Fayetteville \\ 72701; S. T. Koike, University of California Cooperative Extension, Salinas 93901; and T. E. Morelock, Depart- \\ ment of Horticulture, University of Arkansas, Fayetteville
}

\begin{abstract}
Irish, B. M., Correll, J. C., Koike, S. T., and Morelock, T. E. 2007. Three new races of the spinach downy mildew pathogen identified by a modified set of spinach differentials. Plant Dis. 91:1392-1396.

Spinach downy mildew, caused by Peronospora farinosa f. sp. spinaciae, is the most economically important disease of spinach worldwide. During the past few years, spinach cultivars resistant to the seven previously described races of $P$. farinosa f. sp. spinaciae were observed to be severely affected by downy mildew in both the United States and the European Union. Four new isolates of $P$. farinosa f. sp. spinaciae were collected from California and The Netherlands and characterized based on disease reactions on two modified sets of spinach differentials. The results led to the description of three new races of the downy mildew pathogen, designated races 8 , 9 , and 10. Four differential cultivars with resistance to races 1 to 7 were used to distinguish the three new races. Dolphin was susceptible to races 8 and 10 but resistant to race 9; Lion was susceptible to race 10 but resistant to races 8 and 9; Lazio was resistant to races 1 to 7 as well as races 8,9 , and 10; and Tarpy was susceptible to all three new races. The three new races also were used to evaluate the disease reactions on 43 contemporary commercial spinach cultivars in greenhouse trials. A survey of 58 isolates of P. farinosa f. sp. spinaciae collected in California and Arizona between 2004 and 2006 revealed that race 10 predominated in the areas sampled.
\end{abstract}

Spinach (Spinacia oleracea) has become an increasingly popular vegetable crop in the United States. Production estimates indicate that approximately 23,000 ha of spinach were grown in 2005 , with an estimated value of $\$ 170$ million. The largest increases have been with fresh market spinach, where production increased from approximately 134,000 metric tons in 1998 to over 317,000 metric tons in 2005 . The per capita consumption has increased from $0.3 \mathrm{~kg} /$ person in 1995 to approximately 1.0 $\mathrm{kg} /$ person in 2005 (20); this represents a $214 \%$ increase in fresh market spinach consumption in the past 10 years. The increase in consumption has occurred largely due to the convenience and quality of spinach in prepackaged salad mixes and

Corresponding author: J. C. Correll

E-mail: jcorrell@uark.edu

Mention of trade names or commercial products in this article is solely for the purpose of providing specific information and does not imply recommendation or endorsement by the United States Department of Agriculture.

* The $\boldsymbol{e}$-Xtra logo stands for "electronic extra" and indicates that a supplemental figure not included in the print edition appears online.

Accepted for publication 10 June 2007.

doi:10.1094/PDIS-91-11-1392

(c) 2007 The American Phytopathological Society bagged spinach products, as well as consumer recognition of the health benefits of spinach $(1,20)$.

There have been a number of substantial changes in spinach production practices to keep up with production demands. These changes have included year-round production in California and the use of much higher seeding rates and population densities. The impact of these changes on diseases has not been fully assessed. Downy mildew, or blue mold, caused by Peronospora farinosa $\mathrm{f}$. sp. spinaciae Byford (2), is perhaps the most important disease of spinach worldwide (9). As of 2003, seven races of the pathogen had been described, designated race 1 to 7 (15). Although major (qualitative) and minor (quantitative) gene resistance to the various downy mildew races has been identified in spinach (3-6,10,15,17,18), major gene resistance has been most widely used to manage this disease (6). The recent identification of races 5,6 , and 7 of $P$. farinosa f. sp. spinaciae led to the release of many spinach cultivars with resistance to these new races (15; Table 1). However, soon after the release of cultivars with resistance to all of the described races of the pathogen, a number of these newer cultivars were observed to be severely affected by downy mildew in both the United States and the European Union. As a result, efforts were undertaken to identify and characterize the putatively new virulence phenotypes.
The primary objective of this research was to determine whether new races of the spinach downy mildew pathogen were present in spinach-production regions, in the United States and the European Union, based on the disease reactions on a set of modified differential spinach cultivars in greenhouse inoculation tests with isolates of $P$. farinosa f. sp. spinaciae collected in both regions. In addition, a collection of commercial spinach cultivars, most of which have resistance to races 1 to 7 of $P$. farinosa f. sp. spinaciae, were evaluated for resistance to the three new races. A survey of isolates of the pathogen also was conducted in California and Yuma, AZ between 2004 and 2006 to determine which races predominated.

\section{MATERIALS AND METHODS}

Planting. Untreated spinach seed was sown directly into Redi-Earth Mix (ScottSierra, Marysville, $\mathrm{OH})$ in flats $(26 \mathrm{~cm}$ wide by $52 \mathrm{~cm}$ long by $6 \mathrm{~cm}$ tall) with 10 evenly spaced rows of 20 seeds/row. Plants were grown in a greenhouse in which temperatures ranged from 15 to $25^{\circ} \mathrm{C}$. Plants were watered daily and fertilized once a week, beginning 7 days after planting, with an all-purpose fertilizer, Peters 13-13-13 (JR Peters Inc., Allentown, PA).

Experimental design. Each downy mildew race identification experiment was set up as a randomized complete block design with three replications. Each isolate was tested a minimum of twice on each set of differential spinach cultivars.

Isolates for race identification. Four isolates of $P$. farinosa f. sp. spinaciae were used initially in the study. Isolates UMB1 obtained from cv. Umbria, TARP1 from cv. Tarpy, and INT1 from cv. Interceptor were collected from spinach fields in the Salinas Valley in Monterey County, CA in 2003, 2004, and 2004, respectively. A fourth isolate, BB, obtained from The Netherlands on cv. Tigercat, was collected in 2004 (Table 2). All four isolates were recovered from spinach cultivars with reported resistance to races 1 to 7 of $P$. farinosa f. sp. spinaciae. All isolates were stored on infected plant material at $-20^{\circ} \mathrm{C}$ until they could be processed and characterized.

Inoculum preparation. Inoculum of each isolate of $P$. farinosa f. sp. spinaciae was recovered from either spinach leaves 
Table 1. History of the occurrence of races of the spinach downy mildew pathogen, Peronospora farinosa f. sp. spinaciae

\begin{tabular}{|c|c|c|}
\hline Race, year ${ }^{\mathrm{a}}$ & Location & Reference \\
\hline \multicolumn{3}{|l|}{ Race 1} \\
\hline 1824 & United States, Europe & 13,26 \\
\hline \multicolumn{3}{|l|}{ Race 2} \\
\hline 1958 & California & 27 \\
\hline 1958 & Europe & 25 \\
\hline \multicolumn{3}{|l|}{ Race 3} \\
\hline 1976 & The Netherlands & 11 \\
\hline 1978 & California & 12 \\
\hline 1982 & Texas & 17 \\
\hline \multicolumn{3}{|l|}{ Race 4} \\
\hline 1990 & California & 7 \\
\hline 1990 & Japan & 24 \\
\hline 1991 & California & 3 \\
\hline 1991 & Texas & 3 \\
\hline 1994 & Europe & 19 \\
\hline \multicolumn{3}{|l|}{ Race 5} \\
\hline 1996 & Colorado & J. Schafer, unpublished \\
\hline 1997 & California & 8 \\
\hline 1998 & Europe & J. Schafer, unpublished \\
\hline 1998 & Florida & 16 \\
\hline 2006 & Japan & 22 \\
\hline \multicolumn{3}{|l|}{ Race 6} \\
\hline 1998 & California & 8 \\
\hline 2002 & Japan & 23 \\
\hline \multicolumn{3}{|l|}{ Race 7} \\
\hline 1998 & Europe & 21 \\
\hline 2004 & California & 2004, this study \\
\hline \multicolumn{3}{|l|}{ Race 8} \\
\hline 2004 & Europe & 2004, this study \\
\hline \multicolumn{3}{|l|}{ Race 9} \\
\hline 2004 & California & 2004, this study \\
\hline \multicolumn{3}{|l|}{ Race 10} \\
\hline 2004 & California & 2004, this study \\
\hline
\end{tabular}

a Year the race was observed or reported. stored at $-20^{\circ} \mathrm{C}$ or leaves collected directly from the field. Inoculations were conducted as previously described $(3,5)$. Briefly, leaves were placed in a flask containing chilled $\left(4^{\circ} \mathrm{C}\right)$ distilled water, shaken vigorously, and poured through two layers of cheesecloth to remove debris. To produce fresh inoculum, the spore suspension, which was adjusted to 2.0 to $3.0 \times$ $10^{5}$ spores $/ \mathrm{ml}$, was sprayed onto 10 - to 14 day-old spinach seedlings of cv. Viroflay grown as described above. Inoculations were performed with a diaphragm air compressor (Model 80-2; Badger Air Brush Co., Franklin Park, IL). Plants were incubated in a dew chamber, maintained at $18^{\circ} \mathrm{C}$ and $100 \%$ relative humidity for $24 \mathrm{~h}$, and then incubated in a growth chamber at $20^{\circ} \mathrm{C}$ with a 12-h-light, 12-h-dark cycle for 6 days. On the sixth day, plants were returned to the dew chamber and maintained at $18^{\circ} \mathrm{C}$ and $100 \%$ relative humidity for 24 $\mathrm{h}$ to induce sporulation. This inoculum increase cycle on cv. Viroflay typically was performed twice for each isolate in order to produce sufficient fresh inoculum for additional inoculations onto the differential lines.

Race identification. Isolates of $P$. farinosa $\mathrm{f}$. sp. spinaciae were used to inoculate two sets of differential spinach cultivars as well as a collection of commercial cultivars known to differ in resistance to the various races of the pathogen (Tables 2

Table 2. Disease reactions of the U.S. and Naktuinbouw European Union spinach differential sets to races 1 to 10 of the downy mildew pathogen, Peronospora farinosa f. sp. spinaciae

\begin{tabular}{|c|c|c|c|c|c|c|c|c|c|c|c|c|}
\hline \multirow[b]{3}{*}{ Differential cvs. } & \multirow[b]{3}{*}{ Resistance $^{\mathrm{b}}$} & \multirow[b]{3}{*}{ Seed company } & \multicolumn{10}{|c|}{ Race and isolate $^{a}$} \\
\hline & & & R1 & $\mathbf{R 2}$ & $\mathbf{R 3}$ & $\mathbf{R 4}$ & $\mathbf{R 5}$ & R6 & $\mathbf{R 7}$ & $\mathbf{R 8}$ & R9 & $\mathbf{R} 10$ \\
\hline & & & na & na & na & na & FL1 & SP1 & UMB1 & BB & TARP1 & INT1 \\
\hline \multicolumn{13}{|l|}{ United States } \\
\hline Viroflay & None & Chriseed & + & + & + & + & + & + & + & + & + & + \\
\hline Resistoflay & 1,2 & Chriseed & - & - & + & + & + & + & + & + & + & + \\
\hline Califlay & $1,3,5,8,9$ & Chriseed & - & + & - & + & - & + & + & - & - & + \\
\hline Polka & $1,2,3,5(6)$ & Seminis & - & - & - & + & - & + & + & - & - & + \\
\hline Bolero & $1,2,3,4(6)$ & Seminis & - & - & - & - & + & + & + & + & + & + \\
\hline St. Helens & $1,2,3,5,8,9$ & Chriseed & - & - & - & + & - & + & + & - & - & + \\
\hline Whitney & $1,2,3,4$ & Chriseed & - & - & - & - & + & + & + & + & + & + \\
\hline Rushmore & $1,3,4,5,8,9$ & Chriseed & - & + & - & - & - & + & + & - & - & + \\
\hline Campania & $1,2,3,4,(5), 7$ & Pop Vriend & _- & - & - & _- & + & + & - & + & + & + \\
\hline Lion & $1,2,3,4,5,6,7,89$ & Rijk Zwaan & - & - & - & - & - & - & - & - & - & + \\
\hline \multicolumn{13}{|l|}{ Naktuinbouw } \\
\hline NAKT 1 (Winterreuzen) & None & & + & + & + & + & + & + & + & + & + & + \\
\hline NAKT 2 (Nores) & 1,2 & Chriseed & - & - & + & + & + & + & + & + & + & + \\
\hline NAKT 3 (Califlay) & $1,3,5,8,9$ & Seminis & - & + & - & + & - & + & + & - & - & + \\
\hline NAKT 4 (Polka) & $1,2,3,5,8,9$ & Seminis & - & - & - & + & - & + & + & - & - & + \\
\hline NAKT 5 (Rushmore) & $1,3,4,5,8,9$ & Chriseed & - & + & - & - & - & + & + & - & - & + \\
\hline NAKT 6 (Bolero) & $1,2,3,4$ & Seminis & - & - & - & - & + & + & + & + & + & + \\
\hline NAKT 7 (Spinnaker) & $1,2,3,4,5,8,9$ & Bejo & - & - & - & - & - & + & + & - & - & + \\
\hline NAKT 8 (Spicer) & $1,2,3,4$ & Bejo & - & - & - & - & + & + & + & + & + & + \\
\hline NAKT 9 (San Felix) & $1,2,3,4,5,8,9$ & & - & - & - & - & - & + & + & - & - & + \\
\hline NAKT 10 (Clermont) & $1,2,3,4$ & Rijk Zwaan & - & - & - & - & + & + & + & + & + & + \\
\hline NAKT 11 (Lion) & $1,2,3,4,5,6,7,8,9$ & Rijk Zwaan & - & - & - & - & - & - & - & - & - & + \\
\hline NAKT 12 (Scenic) & $1,2,3,4,(5), 7$ & Pop Vriend & - & - & - & - & + & + & - & + & + & + \\
\hline NAKT 13 (El Dorado) & $1,2,3,4,5,7,8,9,10$ & Syngenta & - & - & - & - & - & - & - & - & - & - \\
\hline NAKT 14 (Eagle) & $1,2,3,4,5,6,7$ & Rijk Zwaan & - & - & - & - & + & + & + & + & + & + \\
\hline
\end{tabular}


and 3). One set of differentials was assembled from open-pollinated and hybrid cultivars common to spinach production in the United States. The second set of differentials originated from a standard set of cultivars used by Naktuinbouw in the European Union to test for resistance to races of downy mildew (Dr. Diederik Smilde, personal communication). The latter set of differentials is designated Naktuinbouw in this study (Table 2). Because the isolates were recovered from spinach cultivars known to be resistant to races 1 to 7 of the downy mildew pathogen, further characterization was warranted.

A collection of 43 commercial cultivars, including cultivars from which these particular isolates were recovered, then was evaluated for reaction to the four newly described isolates of the pathogen. The commercial lines also were evaluated for susceptibility to two previously described isolates (FL1 [race 5] and SP1 [race 6]; 15,16). The collection of commercial cultivars consisted of contemporary material developed by various breeding companies and which was commercially available to spinach producers.

For each isolate of $P$. farinosa $\mathrm{f}$. sp. spinaciae, 14-day-old spinach seedlings of the appropriate set of differential cultivars were inoculated with a sporangial suspension $\left(2.0\right.$ to $3.0 \times 10^{5}$ sporan$\mathrm{gia} / \mathrm{ml}$ ), incubated at $100 \%$ relative humidity and $20^{\circ} \mathrm{C}$ for $24 \mathrm{~h}$, and then incubated in the growth chamber as described above. Six days after inoculation, plants were returned to the dew chamber and maintained at $20^{\circ} \mathrm{C}$ and $100 \%$ relative humidity for $18 \mathrm{~h}$.

Disease rating. After a 24 -h period of incubation in a dew chamber to induce sporulation of $P$. farinosa f. sp. spinaciae, cotyledons of the spinach cultivars were evaluated qualitatively for sporulation of the pathogen. Any cotyledon showing symptoms and sporulation was considered susceptible. Any genotype with $>85 \%$ of the cotyledons affected was considered susceptible, whereas any genotype with $<15 \%$ of the cotyledons rated as susceptible was considered resistant, as previously described (3). Intermediate reactions were so noted.

Race characterization survey. In all, 84 isolates of $P$. farinosa f. sp. spinaciae were recovered from spinach samples col-

Table 3. Disease reactions of commercial spinach cultivars to races 1 to 10 of the downy mildew pathogen, Peronospora farinosa f. sp. spinaciae

\begin{tabular}{|c|c|c|c|c|c|c|c|c|c|c|c|c|}
\hline \multirow[b]{3}{*}{ Differential cvs. } & \multirow[b]{3}{*}{ Resistance $^{b}$} & \multirow[b]{3}{*}{ Seed company } & \multicolumn{10}{|c|}{ Race and isolate $\mathrm{e}^{\mathrm{a}}$} \\
\hline & & & $\mathbf{R 1}$ & $\mathbf{R 2}$ & R3 & R4 & R5 & R6 & $\mathbf{R 7}$ & R8 & R9 & R10 \\
\hline & & & na & na & na & na & FL1 & SP1 & UMB1 & BB & TARP1 & INT1 \\
\hline 7-Green & $1,2,3,4,5,6,7$ & Palmer & - & - & - & - & \pm & + & + & - & + & + \\
\hline Avanti & $1,2,3,4,5$ & Rijk Zwaan & - & - & - & - & - & + & + & - & - & + \\
\hline Avenger & $1,2,3,4,5,6,7$ & Seminis & - & - & - & - & ne & - & - & + & - & + \\
\hline Bison & $1,2,3,4,5,6,7$ & Rijk Zwaan & - & - & - & - & ne & - & - & + & - & + \\
\hline Castor & $1,2,3,4,6$ & Daenfeldt & - & - & - & - & \pm & + & + & - & + & + \\
\hline Cezanne & $1,2,3,4,5,6,7$ & Daenfeldt & - & - & - & - & - & - & - & + & + & + \\
\hline Cheetah & $1,2,3,4,5,6,7$ & Rijk Zwaan & - & - & - & - & - & - & - & + & - & + \\
\hline Cherokee & $1,2,3,4,5,6,7$ & Seminis & - & - & - & - & ne & - & - & + & - & + \\
\hline Dolphin & $1,2,3,4,5,6,7$ & Rijk Zwaan & - & - & - & - & - & - & - & + & - & + \\
\hline Eagle & $1,2,3,4,(5,6,7)$ & Rijk Zwaan & - & - & - & - & + & + & + & + & + & + \\
\hline El Dorado & $\ldots$ & Syngenta & $\ldots$ & $\ldots$ & $\ldots$ & $\ldots$ & $\ldots$ & - & - & - & - & - \\
\hline El Palmar & $1,2,3,4,5,6,7$ & Syngenta & - & - & - & - & ne & - & - & - & - & - \\
\hline Emilia & $1,2,3,4,5,6,7$ & Pop Vriend & - & - & - & - & - & - & - & - & - & - \\
\hline Falcon & $1,2,3,4,5,6,7$ & Seminis & - & - & - & - & ne & - & - & + & - & + \\
\hline Hellcat & $1,2,3,4,5,6,7$ & Seminis & - & - & - & - & ne & - & - & + & - & + \\
\hline Hydra & $1,2,3,4,5$ & Rijk Zwaan & - & - & - & - & - & + & + & - & - & + \\
\hline Interceptor & $1,2,3,4,5,6,7$ & Seminis & - & - & - & - & ne & - & - & + & - & + \\
\hline Kerdion & $1,2,3,4,5$ & Daenfeldt & - & - & - & - & - & + & + & - & - & + \\
\hline Lazio & $1,2,3,4,5$ & Pop Vriend & - & - & - & - & ne & - & - & - & - & - \\
\hline Lombardia & $1,2,3,4,5$ & Pop Vriend & - & - & - & - & ne & - & - & - & - & - \\
\hline Medania & $1,3,5$ & Chriseed & - & + & - & + & - & + & + & - & - & + \\
\hline Mig & $1,2,3,4,5,6,7$ & Seminis & - & - & - & - & ne & - & - & + & - & + \\
\hline Mistral & $\ldots$ & Daenfeldt & ne & ne & - & - & - & - & + & - & - & + \\
\hline Monet & $1,2,3,4,5,6,7$ & Daenfeldt & - & - & - & - & - & - & - & + & + & + \\
\hline Nordic IV & $1,2,3,4$ & Syngenta & - & - & - & - & - & + & + & - & - & + \\
\hline Regiment & $1,2,3,4,5,6,7$ & Bejo & - & - & - & - & - & - & - & + & - & + \\
\hline Regina & $\ldots$ & Bejo & ne & ne & ne & ne & ne & - & - & + & - & + \\
\hline Rendo & $\ldots$ & Bejo & ne & ne & ne & ne & ne & - & - & + & - & + \\
\hline Renegade & $1,2,3,4,5,6,7$ & Bejo & - & - & - & - & - & - & - & + & - & + \\
\hline Shasta & $1,2,3,5$ & Chriseed & - & - & - & + & - & + & + & - & - & + \\
\hline Space & $1,2,3,4,5$ & Bejo & - & - & - & - & - & + & + & - & - & + \\
\hline Spinnaker & $1,2,3,5$ & Bejo & - & - & - & + & - & + & + & - & - & + \\
\hline Sporter & $\ldots$ & Bejo & - & - & - & - & - & - & + & - & - & + \\
\hline Springer & $\ldots$ & & ne & ne & ne & ne & ne & ne & ne & + & ne & + \\
\hline Springfield & $\ldots$ & Bejo & ne & ne & ne & ne & - & + & + & - & + & + \\
\hline Sunny & $1,2,3,4,5,6,7$ & Daenfeldt & - & - & - & - & - & - & - & + & + & + \\
\hline Tarpy & $1,2,3,4,5,6,7$ & Enza & - & - & - & - & - & - & - & + & + & + \\
\hline Tigercat & $1,2,3,4,5,6,7$ & Seminis & - & - & - & - & ne & - & - & + & - & + \\
\hline Umbria & $1,2,3,4,5,6,7$ & Pop Vriend & - & - & - & - & + & + & + & - & - & + \\
\hline Santana & $1,2,3,4,5$ & Seminis & - & - & - & - & - & + & + & - & - & + \\
\hline Van Gogh & $1,2,3,4,5,6,7$ & Daenfeldt & - & - & - & - & - & - & - & + & + & + \\
\hline Veneto & $1,2,3,4,5(6) 7$ & Pop Vriend & - & - & - & - & + & + & - & + & + & + \\
\hline Whale & $1,2,3,4,5(6) 7$ & Rijk Zwaan & - & - & - & - & - & + & + & - & - & + \\
\hline Wolter & $1,2,3,5$ & Syngenta & - & - & - & + & - & + & + & - & - & + \\
\hline
\end{tabular}

a Race designations were based on disease reactions of the differential genotypes: na indicates that the isolate was not given a designation; + indicates that $>85 \%$ of the cotyledons showed evidence of infection and sporulation after 7 days and were considered susceptible; - indicates that $<15 \%$ of the cotyledons showed evidence of infection and sporulation after 7 days and were considered resistant; \pm indicates and intermediate reaction; ne indicates that the cultivar was not evaluated. Data for races 1 to 4 were provided by Naktuinbouw (Diederik Smilde, personal communication).

$\mathrm{b}$ Race numbers in parentheses indicate partial resistance to the indicated race of the pathogen. 
lected from nine counties in CA (Fresno, Imperial, Monterey, Riverside, Santa Barbara, San Benito, Santa Cruz, San Diego, and San Luis Obispo) and the Yuma Valley of Arizona between January 2004 and May 2006. Isolates were characterized by race based on inoculations with either inoculum collected in the field and applied directly onto the spinach differentials, or inoculum increased for one or two cycles on cv. Viroflay and then inoculated onto the two sets of differentials.

\section{RESULTS}

Race identification. The disease reactions on the previously developed United States and Naktuinbouw European Union set of differentials (Table 2) indicated that isolate UMB1 of $P$. farinosa f. $\mathrm{sp}$. spinaciae from California was race 7 (15). Race 7 has not been identified previously in the United States (15). All cultivars in the U.S. differential set were susceptible to UMB1 except for cvs. Campania and Lion; all cultivars in the Naktuinbouw European Union differential set also were susceptible, except for cvs. Lion, Scenic, and El Dorado.

Two newly collected isolates, BB from the Netherlands and TARP1 from California, had the same disease reactions as race 5 isolates on the United States and Naktuinbouw European Union differentials (Table 2). However, on the modified differential set (Table 4), cv. Tarpy was susceptible to isolates BB and TARP1, cv. Dolphin was susceptible to BB but resistant to TARP1, and cv. Lazio was resistant to both isolates. Thus, the new cvs. Tarpy, Dolphin, and Lazio in the modified differential set could distinguish these two new isolates, BB and TARP1, from race 5 and, thus, were designated race 8 and 9 , respectively.

The disease reactions of a fourth isolate of $P$. farinosa f. sp. spinaciae, INT1, in- fected all differential cultivars in both differential sets (Table 2). However, disease reactions on the modified differential set (Table 4) indicated that cvs. Tarpy and Dolphin were susceptible to isolate INT1 and cv. Lazio was resistant. Thus, the disease reactions of isolate INT1 on the modified set of differentials indicated that it was unique and, thus, designated as race 10 (Table 4).

Screening of commercial cultivars. A collection of 43 commercial cultivars, including cultivars from which the four newly collected isolates were recovered, was evaluated for disease reaction to several of the known races as well as the three newly described races of the downy mildew pathogen. The commercial cultivars screened included recently released cultivars that were resistant to the seven previously described downy mildew races, races 1 to 7 . Only 5 cultivars among the 43 tested (El Dorado, El Palmar, Emilia, Lazio, and Lombardia) were resistant to races 8,9 , and 10 (Table 3 ).

Race characterizing survey. In all, 59 of 84 samples collected in the Salinas Valley of California and the Yuma Valley of Arizona were characterized for race. Poor viability of inoculum collected in the field resulted in the inability to test 26 of the samples collected. Of the isolates evaluated, the majority (49 of 59) were identified as race 10 (data not shown). One isolate collected in 2004 and a second isolate collected in 2005 were identified as race 4. Three isolates collected in 2004 and 2006 were identified as race 6 . Three isolates collected in 2006 were race 5, and an additional two isolates from 2006 were identified as race 7 (data not shown).

\section{DISCUSSION}

In this study, three new races of the spinach downy mildew pathogen (races 8 , 9 , and 10) were identified based on disease reactions on two previously developed and a new modified set of spinach differentials in greenhouse inoculation experiments. Thus, 10 races of the downy mildew pathogen have now been identified. Additionally, a single isolate of $P$. farinos $a$ f. sp. spinaciae, UMB1, recovered in Salinas Valley, CA, was identified as race 7, which previously was known to occur only in Europe (15). Two isolates, TARP1 and INT1, recovered from the United States had unique disease reactions and were designated as races 9 and 10, respectively. A fourth isolate, BB, from the Netherlands, also had unique disease reactions and was designated as race 8 . In this study, isolates BB and TARP1 initially could not be distinguished from race 5 based on disease reactions on the previously used United States and Naktuinbouw European Union spinach differentials (15). However, because these isolates were recovered from cultivars resistant to races 1 to 7 of the pathogen, it was apparent that the differentials previously used needed to be modified. Thus, after screening commercially available cultivars, a modified set of differentials was developed (Table 4); the modified set of differentials enabled the discrimination of races 8,9 , and 10 from the previously identified races 1 to 7 .

Characterizing the race structure of populations of the spinach downy mildew pathogen is important to both seed companies and spinach producers. The correct documentation and continued survey of races of the downy mildew pathogen is crucial for understanding the virulence diversity of this pathogen as well as for coordinating breeding efforts to develop disease-resistant cultivars. When breeders screening spinach germplasm identify resistance to a new race of the downy mildew pathogen, the resistance then is incorporated into open-pollinated cultivars or, more often, into hybrids. Consequently, the

Table 4. Disease reactions of a modified set of U.S. spinach differential cultivars to races 1 to 10 of the downy mildew pathogen, Peronospora farinosa f. sp. spinaciae

\begin{tabular}{|c|c|c|c|c|c|c|c|c|c|c|c|c|}
\hline \multirow[b]{3}{*}{ Differentials $^{\mathbf{b}}$} & \multirow[b]{3}{*}{ Resistance $^{c}$} & \multirow[b]{3}{*}{ Seed company } & \multicolumn{10}{|c|}{ Race and isolate ${ }^{a}$} \\
\hline & & & R1 & $\mathbf{R 2}$ & $\mathbf{R 3}$ & $\mathbf{R 4}$ & R5 & R6 & $\mathbf{R 7}$ & R8 & R9 & R10 \\
\hline & & & na & na & na & na & FL1 & SP1 & UMB1 & BB & TARP1 & INT1 \\
\hline Viroflay & None & Chriseed & + & + & + & + & + & + & + & + & + & + \\
\hline Resistoflay & 1,2 & Chriseed & - & - & + & + & + & + & + & + & + & + \\
\hline Califlay & $1,3,5,8,9$ & Chriseed & - & + & - & + & - & + & + & - & - & + \\
\hline Polka & $1,2,3,5,(6), 8,9$ & Seminis & _- & _- & _- & + & _- & + & + & _- & _- & + \\
\hline Bolero & $1,2,3,4(6)$ & Seminis & - & - & - & - & + & + & + & + & + & + \\
\hline Campania & $1,2,3,4,(5), 7$ & Pop Vriend & - & - & - & - & + & + & - & + & + & + \\
\hline Lion & $1,2,3,4,5,6,7,8,9$ & Rijk Zwaan & - & - & _- & - & - & - & - & - & - & + \\
\hline Tarpy & $1,2,3,4,5,6,7$ & Enza & - & - & - & - & - & - & - & + & + & + \\
\hline Dolphin & $1,2,3,4,5,6,7,9$ & Rijk Zwaan & _- & - & _- & - & - & _- & - & + & - & + \\
\hline Lazio & $1,2,3,4,5,6,7,8,9,10$ & Pop Vriend & - & - & - & - & - & - & - & - & - & - \\
\hline
\end{tabular}

${ }^{a}$ Race designations were based on disease reactions of the differential genotypes: na indicates that the isolate was not assigned a designation; + indicates that $>85 \%$ of the cotyledons showed evidence of infection and sporulation after 7 days and were considered susceptible; - indicates that $<15 \%$ of the cotyledons showed evidence of infection and sporulation after 7 days and were considered resistant. Data for races 1 to 4 were provided by Naktuinbouw (Diederik Smilde, personal communication).

${ }^{\mathrm{b}}$ Differentials were modified or updated by the addition of new cultivars that could distinguish the three new races of spinach downy mildew, race 8 , 9 , 10 ; new differentials were assembled and implemented in August 2004.

c Reported resistance; race numbers in parentheses indicate partial resistance to the indicated race of the pathogen. 
resistance used to manage a particular race of $P$. farinosa f. sp. spinaciae by one seed company may not be the same source of resistance (i.e., nonallellic resistance) as that used by another company. For example, some spinach cultivars with resistance to races 1 to 5 were susceptible to race 6 , whereas others were not (15). This example demonstrated that disease resistance genes used by breeding companies can be derived from different sources, or a given resistance gene may function differently when in a different genetic background. This observation also is supported by additional research, whereby a molecular marker linked to a resistance locus for race 6 of the downy mildew pathogen is present in most race-6-resistant cultivars but absent in some commercial cultivars that are resistant to race 6 (B. M. Irish and J. C. Correll, unpublished).

The results of this study also showed that the differential sets of spinach cultivars used to identify races of the pathogen must be evaluated continually and updated regularly to incorporate cultivars with resistance to new races of the downy mildew pathogen as they are documented. New cultivars (open-pollinated or hybrid) can be used to update differential sets if they discriminate the new races.

The appearance of several new races of $P$. farinosa $\mathrm{f}$. sp. spinaciae in both California and the European Union is a concern to seed companies and growers. Breeding lines with resistance to races 1 to 7 as well as to the three new races (races 8,9 , and 10) are now available from several companies. Interestingly, with most of the recently identified races of the pathogen, with the exception of race 10, previously identified sources of resistance have been effective to some of the newer races. For example, the older cv. Califlay, originally reported to have resistance to races 1 and 3 (11), subsequently has been shown to also have resistance to races 5,8 , and 9 . When qualitative (major gene) resistance to a new race of the downy mildew pathogen is not identified, the quantitative (minor gene) resistance present in many cultivars (15) may need to be utilized more fully to manage spinach downy mildew.

The mechanisms by which new races of the downy mildew pathogen appear in such a short period and become distributed worldwide is unknown. However, several factors could contribute to the appearance of new races and their subsequent distribution. First, spinach acreage in California has increased significantly in recent years due to expanded markets for salad mixes and washed and packaged spinach $(1,20)$. Second, and partly as a result of the increase in markets, spinach typically is now grown year-round in California. Third, production of 'baby leaf' and 'clip' spinach requires exceptionally high plant densities of 5 to $12 \mathrm{million}$ seed/ha or 28 to
$56 \mathrm{~kg} \mathrm{seed} / \mathrm{ha}$, versus 1.0 to 6.0 million $\mathrm{seed} / \mathrm{ha}$ or 10 to $28 \mathrm{~kg}$ seed/ha for conventional spinach production (S. Koike, unpublished; J. Schafer, personal communication). Fourth, oospores of $P$. farinosa $\mathrm{f}$. sp. spinaciae can be seedborne, and new races could have been introduced into spinach production areas on infested seed (14), particularly if seed does not contain a fungicide seed treatment, such as metalaxyl. The lack of fungicidal seed treatments in organic production, which is popular in California, might be an avenue for disease spread; although no oospores have been observed or documented on seed or leaves in California ( $\mathrm{S}$. Koike, unpublished). Lastly, it also has been hypothesized that $\mathrm{El}$ Niño and La Niña weather patterns in California could have contributed to the increase of new races of the pathogen (15).

Research efforts on downy mildew need to remain focused on monitoring and characterizing races of the pathogen. Most commercial spinach cultivars with resistance genes to downy mildew races are hybrids; therefore, it is important that a set of open-pollinated, isogenic differentials be developed which contain different resistance genes. In addition, resistance breeding efforts should continue to evaluate and utilize quantitative resistance to this important disease. Moreover, the maintenance of reference isolates representing the various races is critical to developing a better understanding of resistance to this important pathogen.

\section{ACKNOWLEDGMENTS}

Portions of this study were supported, in part, by The California Spinach Research Committee. We thank B. Mou, T. Porch, and L. du Toit for their critical review of the manuscript; and J. Schafer and K. Kammeijer for their technical assistance.

\section{LITERATURE CITED}

1. Acharya, R, and Molina, I. 2005. U.S. lettuce and spinach market watch and outlook. NFAPP's Newsletter, Second Quarter 2005. Online publication.

2. Brandenberger, L. P., Correll, J. C., and Morelock, T. E. 1991. Nomenclature of the downy mildew fungus on spinach. Mycotaxon 41:157160.

3. Brandenberger, L. P., Correll, J. C., Morelock, T. E., and McNew, R. W. 1991. Identification of and cultivar reactions to a new race (race 4) of Peronospora farinosa f. sp. spinaciae on spinach in the United States. Plant Dis. 75:630-634.

4. Brandenberger, L. P., Correll, J. C., Morelock, T. E., and McNew, R. W. 1994. Characterization of resistance of spinach to white rust ( $\mathrm{Al}$ bugo occidentalis) and downy mildew (Peronospora farinosa f. sp. spinaciae). Phytopathology 84:431-437.

5. Brandenberger, L. P., Morelock, T. E., and Correll, J. C. 1992. Evaluation of spinach germplasm for resistance to a new race (race 4) of Peronospora farinosa f. sp. spinaciae. HortScience 27:1118-1119.

6. Correll. J. C. 1998. Review of the biology of Peronospora farinosa f. sp. spinaciae. In: Crop Protection Compendium. CAB International, Wallingford, UK.
7. Correll, J. C., Koike, S. T., Brandenberger, L. P., Black, M. C., and Morelock, T. E. 1990. A new race of downy mildew threatens spinach. Calif. Agric. 44:14-15.

8. Correll, J. C., Koike, S. T., Schafer, J., Anders, J. M., Irish, B. M., and Morelock, T. E. 1998. Two new races of the downy mildew pathogen (Peronospora farinosa f. sp. spinaciae) of spinach in the United States. (Abstr.) Phytopathology 88:S19.

9. Correll, J. C., Morelock, T. E., Black, M. C., Koike, S. T., Brandenberger, L. P., and Dainello, F. J. 1994. Economically important diseases of spinach. Plant Dis. 78:653-660.

10. Correll, J. C., Morelock, T. E., and Koike, S. T. 1998. Screening of USDA Spinach Germplasm to Two New Races of the Downy Mildew Pathogen (Peronospora farinosa f. sp. spinaciae). Leafy Vegetable Conference, Atlantic City, NJ.

11. Eenink, A. H. 1976. Linkage of two racespecific genes of Spinacia oleracea L. for resistance to downy mildew Peronospora farinosa f. sp. spinaciae, Byford. Euphytica 25:713-715.

12. Greathead, A. 1980. Spinach mildew fought with breeding and chemicals. West. Grow. Ship. 51:38-39.

13. Greville, R. K. 1824. Flora Edinensis. Blackwood \& Strand, Edinburgh, London.

14. Inaba, T., Takahashi, K., and Morinaka, T. 1983. Seed transmission of spinach downy mildew. Plant Dis. 67:1139-1141.

15. Irish, B. M., Correll, J. C., Koike, S. T., Schafer, J., and Morelock, T. E. 2003. Identification and cultivar reaction to three new races of the spinach downy mildew pathogen (Peronospora farinosa f. sp. spinaciae), from the United States and Europe. Plant Dis. 87:567572.

16. Irish, B. M., Correll, J. C., Raid, R. N., and Morelock, T. E 2004. First report of Peronospora farinosa f. sp. spinaciae (race 5) of spinach in Florida. Plant Dis. 88:84.

17. Jones, R. K., and Dainello, F. J. 1982. Occurrence of race 3 of Peronospora effusa on spinach in Texas and identification of sources of resistance. Plant Dis. 66:1078-1079.

18. Koike, S. T., Smith, R. F., and Schulbach, K. F. 1992. Resistant cultivars, fungicides combat downy mildew of spinach. Calif. Agric. 46:2931.

19. Lorenzini, G., and Nali, C. 1994. A new race (race 4) of spinach downy mildew in Italy. Plant Dis. 78:208.

20. Lucier, G., Allshouse, J., and Lin, B. 2004. Factors affecting spinach consumption in the United States. Econ. Res. Serv. U. S. Dep. Agric. VGS-300-01.

21. Nali, C. 1998. A novel threat for spinach in Italy: A new race of downy mildew. Adv. Hortic. Sci. 12:179-182.

22. Satou, M., Nishi, K, Kubota, M., Fukami, M. Tsuji, H., and Van Ettekoven, K. 2006. Appearance of race 5 of spinach downy mildew fungus, Peronospora farinosa $\mathrm{f}$. sp. spinaciae, in Japan. J. Gen. Plant Pathol. 72:193-194.

23. Satou, M., Sugiura, T., Ohsaki, R., Honda, N., Horiuchi, S., and Yamauchi, N. 2002. A new race of spinach downy mildew in Japan. J. Gen. Plant Pathol. 68:49-51.

24. Shimazaki, Y. 1990. Appearance of a new race 4 of downy mildew on spinach. Ann. Phytopathol. Soc. Jpn. 56:95.

25. Smith, P. G., Webb, R. E., Millett, A. M., and Luhn, C. H. 1961. Downy mildew on spinach. Calif. Agric. 15:5.

26. Smith, W. G. 1885. Disease of spinach, Peronospora effusa Grev. Gard. Chron. 23:480.

27. Zink, F. W., and Smith, P. G. 1958. A second physiologic race of spinach downy mildew. Plant Dis. Rep. 42:818.15. 